

DEN NORSKE LEGEFORENING

\title{
Det var en gang en landslege
}

TIDLIGERE I TIDSSKRIFTET

JULIE DIDRIKSEN

Tidsskriftet

I Tidsskriftets utgave nr. 3/1919 finner vi et innlegg fra en legefrue som hadde sett seg lei av hvordan mannen hennes og andre leger ble behandlet av allmennheten. Hadde de enda blitt kompensert $ø$ konomisk for de uendelig lange arbeidsdagene og uendelig lange reiseveiene, men nei! Lønnen var ikke i nærheten av det den burde være. Dessuten ble de behandlet av sine pasienter på en måte som man ikke engang ville våge å behandle tjenestefolk (Tidsskr Nor Lægeforen 1919;39:105).

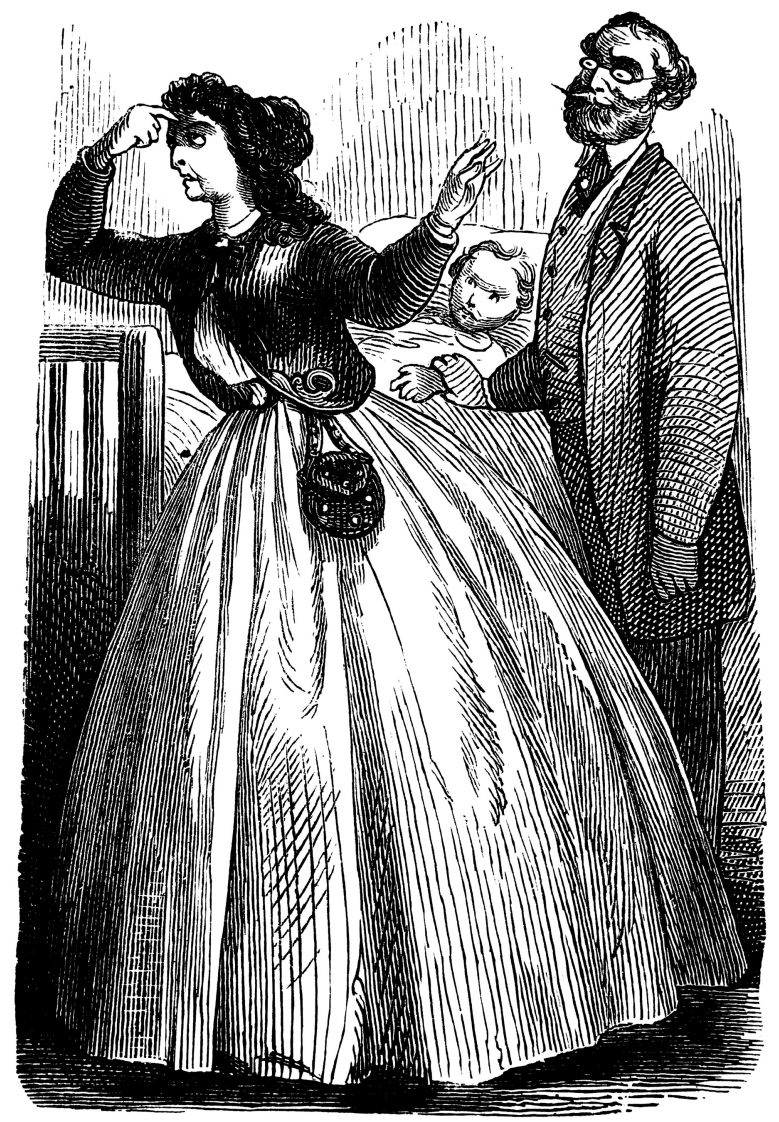

Illustrasjon: maodesign/iStock 


\section{Landslægerne og deres publikum.}

Der var engang en landslæge, som langt om længe hadde faat tak i en vikar, en ældre graaskjegget doktor. Saa ringte natklokken en nat, vikaren trak i underbenklær, satte natluen godt til rette og lukket op. «Je sku ha tak i doktorn!» «Ja, det er mig,» siger lægen. «Nei, den gaar itte, far!» «Ja,» siger lægen, "gaar ikke den, saa gaar du,» og dermed lempet han manden utenfor, gik op og sov rolig videre. - Selv om landslægerne ikke var fuldt saa robuste som denne vikar, kunde det ikke skade, om de en og anden gang sa sin mening. Jeg synes, de fører en altfor «stilfærdig» tilværelse. De blir nemlig ikke altid behandlet paa en synderlig hensynsfuld maate; især under denne influenzaepidemi har det været svært iøinefaldende, at lægen meget ofte oppfattes av sit klientel som i fordums dage en tjener. I vor tid turde man ialfald ikke tiltalte sine tjenestefolk slik, som jeg av og til har hørt en læge bli tiltalt. Lægen svarer t. eks. paa en opringning, at han netop er kommet hjem fra en lang reise, sliten og daarlig, saa "hvis det ikke gjælder livet o. s. v.»--- «Ja, men du skæ komma strast, for du er ansat her.» En anden gang: «Hvorfor kom du itte igaar, det hasta vel itte slik med den kontorda'n din ve?» Og slik i det uendelige. Og det av folk, som selv kræver otte timers arbeidsdag.

Je sku ha tak i doktorn!

Naar dertil kommer, at lægen ofte, ja bestandig under denne influenzaepidemi arbeider uten stans optil 16 à 17 timer i døgnet, at han reiser paa de frygteligste veier, hvor han t. eks. et sted efter at ha kjørt i flere timer maa gaa i 10 timer i bundløs søle og mørke for at naa frem, uten mat, ja da synes jeg, det er et under, at ikke flere læger blir overnervøse. Utslitt blir de ofte i en yngre alder. Hadde de saa endda for alt sit slit rigtig god betaling! Men se det har de heller ikke. Kredssykekassen er ingen god betaler. Den har indskrænket den mere lønnede privatpraksis følelig, da endog meget velstaaende gaardbrukere indmelder sine sønner og døtre der. Kredssykekassen betaler for kontorpraksis $3 \mathrm{kr}$. for første gang og 2 for de efterfølgende. For mindre operationer 5 kr., - for reiser optil $10 \mathrm{~km}$. Bare $11 \mathrm{kr} ., 4 \mathrm{kr}$. for avstig underveis o.s.v. Disse takster staar ikke i nogetsomhelst forhold til den nuværende dyrtid.

I vor tid turde man ialfald ikke tiltalte sine tjenestefolk slik, som jeg av og til har hørt en læge bli tiltalt.

En ting til: Kunde det ikke ordnes saa, at kommunerne rundt om i landet ydet sin læge en maaneds regelmæssig sommerferie med fri vikar? Som det nu er, har jo de færreste landslæger raad til at ta sig ferie, og det aldrig at føle sig helt fri, selv ikke om søndagen, nedsætter uvilkaarlig arbeidsglæden og arbeidskraften.

Landslagefrue.

Publisert: 24. juni 2019. Tidsskr Nor Legeforen. DOI: 10.4045/tidsskr.19.0062

(C) Tidsskrift for Den norske legeforening 2020. Lastet ned fra tidsskriftet.no 